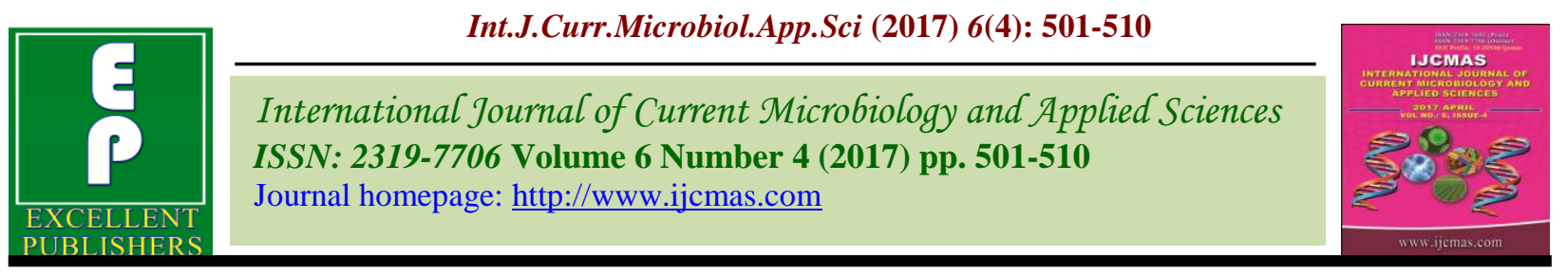

Original Research Article

https://doi.org/10.20546/ijcmas.2017.604.060

\title{
Cultivable Microbial Diversity Study from Traditional Formulation and Characterization of Phosphate Solubilizers through their Effect on Vegetative Growth Parameters of Zea mays L.
}

\author{
Urja Pandya ${ }^{1,2}$, Mukesh Prajapati ${ }^{1}$ and Nirmal S. Sahay ${ }^{1 *}$
}

${ }^{1}$ Sadbhav SRISTI Sanshodhan Natural Products Laboratory, SRISTI, AES Boys Hostel Campus, Nr. Gujarat University Library and SBI, Navrangpura, Ahmedabad, Gujarat, India

${ }^{2}$ Value Addition Research and Development- Human Health, National Innovation FoundationIndia, Satellite Complex, Jodhpur Tekra, Ahmedabad, Gujarat, India

*Corresponding author

\section{A B S T R A C T}

Keywords

Grassroots,

Phosphate

solubilization,

SRISTI, Validation,

Zea mays L.

Article Info

Accepted:

02 March 2017

Available Online:

10 April 2017

Traditional organic farming practices are beneficial but in most of the cases the science behind it is not well understood. The aim of present study was selection of grassroots practice from SRISTI database and its validation for crops growth promotion. Formulation was prepared and studied for their microbial content and growth. Results showed maximum bacterial population as compared to fungi and actinomycetes population. Five bacterial isolates showed phosphate solubilizing activity and these isolates were further studied as bioinoculants for Zea mays L. growth in pot experiment. Seed bacterization with isolate F7B1 (T4 treatment) showed maximum plant height $(52.44 \%)$ and fresh biomass $(202.08 \%)$ after $15^{\text {th }}$ days of sowing as compared to other treatments.

\section{Introduction}

India has a large informal economy. The informal sector is viewed as a source of low technological and labour-intensive employment and has never been considered an area of innovative activity. India is the first country to recognize the innovative ability of the informal sector and to develop and support innovations of the Grass roots. Research on innovative activity at the grassroots level has been performed mainly by the scholars involved in the grassroots innovation (GRI) movement in India. Sadbhav- SRISTI Sanshodhan Natural Products Laboratory is one of its kinds to bridge the gap of informal and formal knowledge by validation and value addition in them for product development (Ustyuzhantseva, 2015). SRISTI has scouted many practices since 1993 and has a large database of more than 50,000 grassroots innovations and traditional knowledge, many of them are available in public domain for the benefit of farmers (www.sristi.org.; http://www.sristi.org/hbnew/honeybee_databa se.php).

Panchagavya, an organic formulation containing cow dung and cow urine in 
addition to cow milk, ghee and curd, has been reported as an efficient plant growth stimulant (Naik and Sreenivasa, 2009). It has been reported that the Effective Micro Organisms (EMO) in Panchagavya are the mixed culture of naturally occurring beneficial microbes: mostly lactic acid bacteria (Lactobacillus), yeast (Saccharomyces), Actinomyces (Streptomyces), photosynthetic bacteria (Rhodopsuedomonas) and certain fungi (Aspergillus), which promote the growth and yield in different crops (Xu, 2001; Swaminathan et al., 2007). Plant growth depends on many nutrients and phosphorous is a limiting macronutrient for plant growth. Phosphate-Solubilizing Bacteria improve plant growth, yield and phosphorus content in several crops, and may be used as bioinoculants to enhance sustainable production. The phosphate solubilizing bacteria may present several plant growth promotion traits, such as $\mathrm{P}$ solubilization (by acidification or phosphatase production), or the production of Indole-3-acetic acid (IAA) and siderophore (Viruel et al., 2014).

The objective of this study was to establish scientific basis for the grassroots practice used by the innovator to achieve better growth and yield of crops. The main objectives were: (1) Preparation of formulation based on innovator's methodology (2) Microbial type and population study from formulation (3) Screening of isolate for their phosphate solubilization property (4) study of phosphate solubilization positive isolates as bioinoculants for Zea mays L. growth under pot experiments.

\section{Materials and Methods}

\section{Innovator's methodology}

Mr. Devshankar bhai Purnashankar bhai Pandya (Innovator) prepares a mixture by using 20 litres of cow urine, $10 \mathrm{~kg}$ of cow dung, 10 litres buttermilk, $5 \mathrm{~kg}$ Jaggery, $5 \mathrm{~kg}$ soil from Ficus tree and $5 \mathrm{~kg}$ of gram flour. He mix all these ingredients and keep it under the shadow of Ficus tree for one week for natural fermentation. Then filter it and uses the solution with drip irrigation and spray the solution twice in a week on various crops and vegetables. We prepared the mixture and kept in a container for 7 days. Samples were withdrawn at 0 day and $7^{\text {th }}$ days from the mixture.

\section{Isolation of microorganisms from mixture}

Sample was studied for their microbial type and population. Serial dilution techniques were used for the isolation of bacteria, fungi and actinomycetes in their standard respective media. Bacteria was isolated in Petri plate containing nutrient agar medium, fungi in petriplate containing potato dextrose agar medium) and Actinomycetes in Petri plate containing actinomycetes isolation agar medium. Numbers of colonies obtained on all these agar plates were counted and their colony characteristics were recorded (Pandya et al., 2014).

\section{Screening of isolates for phosphate solubilizing activity}

All isolates from 0 day and after 7 days of natural fermentation were screened for their phosphate solubilizing activity on Pikovskaya's agar medium (Pikovskaya, 1948). The plates were incubated at $28^{\circ} \mathrm{C}$ for 3-5 days. After incubation the phosphate solubilizing microorganisms were selected based on the area of zone of clearing around the colonies.

\section{Staining and non staining (KOH) method for determination of gram reactions of bacteria}

The direct observation of selected isolates was served as the first characterization comprising the size, shape, margin, elevation, 
opacity, and pigmentation on nutrient agar medium (Zinniel et al., 2002). Each isolate was subjected to Gram stain and $3 \% \mathrm{KOH}$ test for determination of gram reactions (Suslow et al., 1982).

\section{Effect of PSB isolates on growth promotion of Zea mays L. under pot experiments Seed bacterization}

Maize seeds were washed five times with sterilized distilled water. Seeds were coated with $1 \%$ carboxymethyl cellulose (CMC) as adhesive. Then, seeds were treated with bacterial cultures for $30 \mathrm{~min}$. Each bacterial strain was inoculated in $150 \mathrm{ml}$ flask containing $60 \mathrm{ml}$ of pikovskaya's broth medium and incubated at $28 \pm 1{ }^{\circ} \mathrm{C}$ for three days. An optical density of 0.5 recorded at $\lambda$ $535 \mathrm{~nm}$ was achieved by dilution to maintain uniform cell density $\left(10^{8}-10^{9} \quad \mathrm{CFU} / \mathrm{ml}\right)$ (Gholami et al., 2009).

\section{Seed germination}

A daily record was maintained of seed that had emerged out of the surface of soil was kept. Recording of germination was continuing for 7 days. Under germination parameters: daily total, cumulative total, cumulative germination percentage, peak value, germination speed, germination percentage and germination capacity were calculated (Abdul-Baki and Anderson, 1973).

\section{Study of biomass enhancement after $15^{\text {th }}$ DAS (Days after Sowing)}

Treatments included: (T1) Water control (T2) 1\% CMC (T3) F0B1 (T4) F7B1 (T5) F7B3 and (T6) F7B5 and (T7) F7B8 respectively. The experiment was set in a randomized block design (RBD) and three replicates were taken for each set of the experiment. Irrigation was carried out every day with distilled water. Three plants were randomly selected from each treatment and the mean of two plants was used as one replication. Plant height $(\mathrm{cm})$ and fresh biomass $(\mathrm{g})$ of each plant were recorded after $15^{\text {th }}$ DAS (Tank and Saraf, 2008).

\section{Statistical analysis}

All experiential data were calculated for Means and standards error by using Microsoft (MS) excel.

\section{Results and Discussion}

Microbial diversity from 0 and $7^{\text {th }}$ day of formulation

Total 16 bacterial colonies were isolated from $0^{\text {th }}$ day of formulation. Among 16 bacterial isolates, 10 bacterial isolates showed the pigmentation of different colors (Table 1). Maximum numbers of colonies were observed for F0B15 (10 colonies) followed by F0B14 (6 colonies) and F0B11 (5 colonies). After $7^{\text {th }}$ days of formulation, microbial diversity was studied for microbial count. Eight bacterial isolates were obtained (Table 1). Total four types of fungal colonies were observed at $0^{\text {th }}$ day of formulation. The total counts of fungal isolates were $5 \times 10^{4} \mathrm{CFU} / \mathrm{ml}$. After $7^{\text {th }}$ days of formulation, sample was withdrawn and studied for diversity of fungal isolates on PDA plates. Only one type of fungal colony was observed having $1 \times 10^{3} \mathrm{CFU} / \mathrm{ml}$ (Table 2). Two types of actinomycetes were recorded on $0^{\text {th }}$ day of formulation having $1.3 \times 10^{2}$ $\mathrm{CFU} / \mathrm{ml}$. After $7^{\text {th }}$ days of formulation, total five types of actinomycetes were observed having $1.6 \times 10^{3} \mathrm{CFU} / \mathrm{ml}$ (Table 2).

Phosphate solubilization by selected isolates

All isolates were screened for their phosphate solubilizing activity on Pikovskaya's agar medium. Results shows that all the five 
isolates were $\mathrm{P}$ solubilizer and they showed clear zone after 3 days of incubation at $30 \pm 2$ ${ }^{0} \mathrm{C}$. Maximum zone was observed in isolate F7B1 $(16+0.1 \mathrm{~mm})$. Significant zones were also recorded in F7B3 $(13.3+0.057 \mathrm{~mm})$, F7B5 $(12.7+0.05 \mathrm{~mm})$, FOB1 $(12+0.057 \mathrm{~mm})$ and F7B8 $(11+0.1 \mathrm{~mm})$ after 72 hour of incubation (Table 3 ).

The preliminary screening for identification of PSB (Phosphate solubilizing bacteria) confirmed by using $\mathrm{Ca}_{3}(\mathrm{PO} 4)_{2}$ as sole $\mathrm{P}$ source in screening media. The production of clear zones is due to the microbes' ability to solubilize the insoluble tricalcium phosphate or hydroxyapatite present in the medium (Liu et al., 2015). Results indicated that significant bacterial growth or $\mathrm{P}$ solubilization halo zones surrounding bacterial colonies appeared only on plates with $\mathrm{Ca}_{3}(\mathrm{PO} 4)_{2}$, which was in agreement with the reports of Barroso and Nahas (2005), and Son et al., (2006). A large number ofbacteria including species of Pseudomonas, Azospirillum, Azotobacter, Klebsiella, Enterobacter, Alcaligenes, Arthrobacter, Burkholderia, Bacillus, Rhizobium and Serratia have been reported to solubilize phosphate (Kumar et al., 2012).

\section{Gram staining and $\mathrm{KOH}$ test}

On the basis of phosphate solubilizing activity, only five isolates were selected for further studies. All five cultures were identified as Gram positive by Gram staining as well as $\mathrm{KOH}$ test (Table 4).

\section{Pot experiments}

\section{Seed germination analysis}

Daily record of seed germination was carried out for all treatments (Table 5). Maximum germination was recorded by T4 (90\%) followed by T5 (80\%), T6 (70\%), T7 (70\%) and T3 $(60 \%)$ as compared to water control (T1). The maximum cumulative germination percentage i.e. $30.71 \%$ was recorded on $7^{\text {th }}$ day of germination. The highest germination peak value (7.15) and germination speed (10) was recorded on $2^{\text {nd }}$ day of germination and later it was decreased. The highest germination capacity was recorded by $\mathrm{T} 4$ and T5 (90\%) and least was recorded by T1 (40\%) respectively. Similar improvement of seed germination parameters by bacteria has been reported by Jha and Saraf, (2011). They observed that effect of bacterial inoculants on Jatropha seed germination at $28^{\text {th }}$ DAS under pot experiments. Gholami et al., (2009) also reported effect of rhizobacteria on germination, seedling growth and yield of maize under pot experiments. They performed seed germination assay by paper towel method. Filter treatment with biofertilizers showed $37 \%$ of higher germination as compared to control reported by Bakonyi et al., (2013). Similarly, Abiala et al., (2015) reported inoculation of maize seeds with bacterial isolates resulted in $\geq 95 \%$ maize seed germination and significantly enhanced radicle and plumule length.

\section{Effect of bioinoculants on vegetative growth parameters}

Maximum plant height was found in T4 $(52.44 \%)$ followed by T6 $(34.14 \%)$ and T7 $(23.56 \%)$ in comparison with control (T1) respectively. Maximum increase in fresh biomass was observed in plants treated with treatment T4 $(202.08 \%)$ followed by T6 (164.58\%) and T7 (147.92\%) in comparison with control (T1) respectively. The lowest increased fresh biomass was recorded by $\mathrm{T} 8$ (141.672\%). T2 treatment showed higher plant height (16.76\%) and fresh biomass $(102.08 \%)$ as compared to control (T1) respectively (Fig. 1). Similarly, Hussain et al., (2011) reported that rhizobacterial inoculants significantly increased maize plant height (16\%), root length (11\%), shoot dry weight (42\%), root dry weight (29\%) and grain yield $(33 \%)$ over uninoculated control. 
Table.1 Morphological and cultural characteristics of bacterial diversity from mixture

\begin{tabular}{|c|c|c|c|c|c|c|c|c|c|c|c|c|c|}
\hline \multirow{2}{*}{$\begin{array}{l}\text { Sr. } \\
\text { No }\end{array}$} & \multirow{2}{*}{$\begin{array}{l}\text { Type } \\
\text { of } \\
\text { colon } \\
y \\
\end{array}$} & \multirow{2}{*}{$\begin{array}{c}\text { No. } \\
\text { of } \\
\text { colon } \\
y\end{array}$} & \multicolumn{7}{|c|}{ Morphology of Bacteria } & \multirow[t]{2}{*}{ Dilution } & \multirow[t]{2}{*}{ Code } & \multirow[t]{2}{*}{$\mathrm{CFU} / \mathrm{ml}$} & \multirow{2}{*}{$\begin{array}{l}\text { Average } \\
\text { CFU/ml }\end{array}$} \\
\hline & & & Size & Shape & Margin & Elevation & Opacity & $\begin{array}{c}\text { Consiste } \\
\text { ncy }\end{array}$ & $\begin{array}{l}\text { Pigmentati } \\
\text { on }\end{array}$ & & & & \\
\hline 2 & B2 & 1 & S & $\mathrm{R}$ & $\mathrm{E}$ & $\mathrm{F}$ & Opaque & Viscus & Yellow & 1000 & F0B2 & 10000 & \\
\hline 3 & B3 & 1 & B & $\mathrm{R}$ & $\mathrm{E}$ & $\mathrm{F}$ & Opaque & Dry & Nil & 1000 & F0B3 & 10000 & \\
\hline 4 & B4 & 2 & S & $\mathrm{R}$ & $\mathrm{E}$ & $\mathrm{F}$ & Opaque & Dry & L. brown & 1000 & F0B4 & 20000 & \\
\hline 7 & B7 & 1 & $S$ & $\mathrm{R}$ & $\mathrm{E}$ & $\mathrm{Ef}$ & Opaque & Moist & Nil & 1000 & F0B7 & 10000 & \\
\hline 8 & B8 & 4 & $\mathrm{~S}$ & $\mathrm{R}$ & $\mathrm{E}$ & $\mathrm{F}$ & Trans. & Moist & L.brown & 1000 & F0B8 & 40000 & \\
\hline 9 & B9 & 1 & S & $\mathrm{El}$ & $\mathrm{E}$ & $\mathrm{F}$ & Trans. & Dry & Nil & 1000 & F0B9 & 10000 & \\
\hline 10 & B10 & 1 & $\mathrm{~S}$ & $\mathrm{R}$ & $\mathrm{E}$ & $\mathrm{F}$ & Trans. & Moist & L. brown & 1000 & F0B10 & 10000 & \\
\hline 11 & B11 & 5 & S & $\mathrm{R}$ & $\mathrm{E}$ & $\mathrm{F}$ & Trans. & Moist & L. brown & 1000 & F0B11 & 50000 & \\
\hline 16 & B16 & 1 & $S$ & $\mathrm{R}$ & $\mathrm{E}$ & $\mathrm{Ef}$ & Opaque & Moist & Nil & 100000 & F0B16 & 1000000 & \\
\hline \multicolumn{14}{|c|}{ Morphological characteristics of bacteria at $7^{\text {th }}$ day of formulation } \\
\hline 1 & B1 & 1 & B & I & Lobate & Flat & Opaque & Dry & Nil & 100000 & F7B1 & 1000000 & $2 \times 10^{4}$ \\
\hline 2 & B2 & 2 & S & $\mathrm{R}$ & Entire & Flat & Opaque & Dry & Yellow & 10000 & F7B2 & 200000 & \\
\hline 3 & B3 & 1 & B & $\mathrm{R}$ & Entire & Flat & Opaque & Moist & Nil & 100000 & F7B3 & 1000000 & \\
\hline 4 & B4 & 2 & S & $\mathrm{R}$ & Erose & Flat & Opaque & Moist & Shinecream & 1000 & F7B4 & 20000 & \\
\hline 5 & B5 & 2 & $S$ & $\mathrm{R}$ & Entire & Flat & Opaque & Dry & Nil & 1000 & F7B5 & 20000 & \\
\hline 6 & B6 & 1 & B & I & Entire & Flat & Opaque & Dry & Nil & 1000 & F7B6 & 10000 & \\
\hline 7 & B7 & 1 & M & $\mathrm{R}$ & Entire & Flat & Opaque & Dry & L.brown & 10000 & F7B7 & 100000 & \\
\hline 8 & B8 & 7 & $S$ & $\mathrm{R}$ & Entire & Flat & Opaque & Buttery & Nil & 1000 & F7B8 & 70000 & \\
\hline
\end{tabular}


Table.2 Morphological and cultural characteristics of fungi and actinomycetes from mixture

\begin{tabular}{|c|c|c|c|c|c|c|c|c|c|c|c|c|}
\hline \multirow{2}{*}{$\begin{array}{l}\text { Time } \\
\text { Interva } \\
1\end{array}$} & \multirow{2}{*}{$\begin{array}{l}\text { Type } \\
\text { of } \\
\text { Colon } \\
\mathrm{y} \\
\end{array}$} & \multirow{2}{*}{$\begin{array}{l}\text { No. } \\
\text { of } \\
\text { colon } \\
y\end{array}$} & \multirow[t]{2}{*}{ Size } & \multirow[t]{2}{*}{ Shape } & \multirow[t]{2}{*}{ Margin } & \multicolumn{2}{|c|}{ Pigmentation } & \multirow[t]{2}{*}{ Spore } & \multirow[t]{2}{*}{ Code } & \multirow{2}{*}{$\begin{array}{l}\text { Diluti } \\
\text { on }\end{array}$} & \multirow[t]{2}{*}{$\mathrm{CFU}$} & \multirow{2}{*}{$\begin{array}{l}\text { Avera } \\
\text { ge } \\
\text { CFU/ } \\
\text { ml } \\
\end{array}$} \\
\hline & & & & & & $\begin{array}{l}\text { Diffusion } \\
\text { in media }\end{array}$ & Mycelium & & & & & \\
\hline \multirow{3}{*}{$0^{\text {th }}$ day } & $\mathrm{F} 2$ & 2 & Small & Round & Entire & L. yellow & Nil & Nil & F0F2 & 1000 & 2000 & \multirow{3}{*}{$5 \times 10^{4}$} \\
\hline & F3 & 1 & Small & Round & Entire & L. brown & Nil & Nil & F0F3 & 1000 & 10000 & \\
\hline & $\mathrm{F} 4$ & 1 & $\mathrm{M}$ & Round & Entire & Yellow & Nil & Brown & $\mathrm{F} 0 \mathrm{~F} 4$ & 1000 & 10000 & \\
\hline \multirow{2}{*}{$\begin{array}{l}\text { Time } \\
\text { Interva } \\
1\end{array}$} & \multirow{2}{*}{$\begin{array}{l}\text { Type } \\
\text { of } \\
\text { Colon } \\
y\end{array}$} & \multirow{2}{*}{$\begin{array}{l}\text { No. } \\
\text { of } \\
\text { colon } \\
\text { y }\end{array}$} & \multirow[t]{2}{*}{ Size } & \multirow[t]{2}{*}{ Shape } & \multirow[t]{2}{*}{ Margin } & \multicolumn{2}{|c|}{ Pigmentation } & \multirow{2}{*}{$\begin{array}{c}\text { Other } \\
\text { characteri } \\
\text { stics }\end{array}$} & \multirow[t]{2}{*}{ Code } & \multirow{2}{*}{$\begin{array}{l}\text { Diluti } \\
\text { on }\end{array}$} & \multirow[t]{2}{*}{$\overline{\mathrm{CFU}}$} & \multirow{2}{*}{$\begin{array}{l}\text { Avera } \\
\text { ge } \\
\text { CFU/ } \\
\text { ml } \\
\end{array}$} \\
\hline & & & & & & $\begin{array}{l}\text { Diffusion } \\
\text { in media }\end{array}$ & $\begin{array}{l}\text { Colony } \\
\text { color }\end{array}$ & & & & & \\
\hline $0^{\text {th }}$ day & A1 & 13 & Small & $\begin{array}{c}\text { Punctiof } \\
\text { orm }\end{array}$ & Entire & L. brown & Nil & - & F0A1 & 100 & 1300 & $\begin{array}{l}1.3 \mathrm{x} \\
10^{2}\end{array}$ \\
\hline \multirow{3}{*}{$7^{\text {th }}$ day } & A3 & 1 & M & Round & Entire & D. brown & Nil & - & F7A3 & 100 & 1000 & \multirow{3}{*}{$\begin{array}{l}1.6 \mathrm{x} \\
10^{3}\end{array}$} \\
\hline & A4 & 1 & Small & Round & Entire & D. brown & L.brown & - & F7A4 & 100 & 1000 & \\
\hline & A5 & 1 & $\mathrm{Big}$ & Round & Entire & L. brown & Nil & - & F7A5 & 1000 & 10000 & \\
\hline
\end{tabular}

Notes: M= Medium; L= Light, D= Dark 
Table.3 Phosphate solubilization after 72h of incubation on Pikovskaya's agar medium

\begin{tabular}{ccc}
\hline Sr. No. & Name of Isolates & Phosphate solubilization $(\mathrm{mm})$ \\
\hline 1 & FOB1 & $12 \pm 0.057$ \\
2 & F7B1 & $16 \pm 0.1$ \\
3 & F7B3 & $13.3 \pm 0.057$ \\
4 & F7B5 & $12.7 \pm 0.05$ \\
5 & F7B8 & $11 \pm 0.1$ \\
\hline
\end{tabular}

Note: All data were in triplicates and calculated as Mean \pm SD.

Table.4 Results of Gram staining and $\mathrm{KOH}$ test analysis

\begin{tabular}{cccc}
\hline Sr. No. & Sample code & Gram stain & KOH Test \\
\hline 1. & F0B1 & Gram positive & Gram positive \\
2. & F7B1 & Gram positive & Gram positive \\
3. & F7B3 & Gram positive & Gram positive \\
4. & F7B5 & Gram positive & Gram positive \\
5. & F7B8 & Gram positive & Gram positive \\
\hline
\end{tabular}

Figure.1 Effect of PSB strains on vegetative growth parameters of Zea mays L. after $15^{\text {th }}$ DAS under pot experiments $(\mathrm{T} 1=$ Water control, $\mathrm{T} 2=1 \% \mathrm{CMC}, \mathrm{T} 3=\mathrm{F} 0 \mathrm{~B} 1+\mathrm{CMC}, \mathrm{T} 4=\mathrm{F} 7 \mathrm{~B} 1+\mathrm{CMC}$, $\mathrm{T} 5=\mathrm{F} 7 \mathrm{~B} 3+\mathrm{CMC}, \mathrm{T} 6=\mathrm{F} 7 \mathrm{~B} 5+\mathrm{CMC}, \mathrm{T} 7=\mathrm{F} 7 \mathrm{~B} 8+\mathrm{CMC})$. Data for each treatment are the mean of three observations \pm SE (Standard Error)

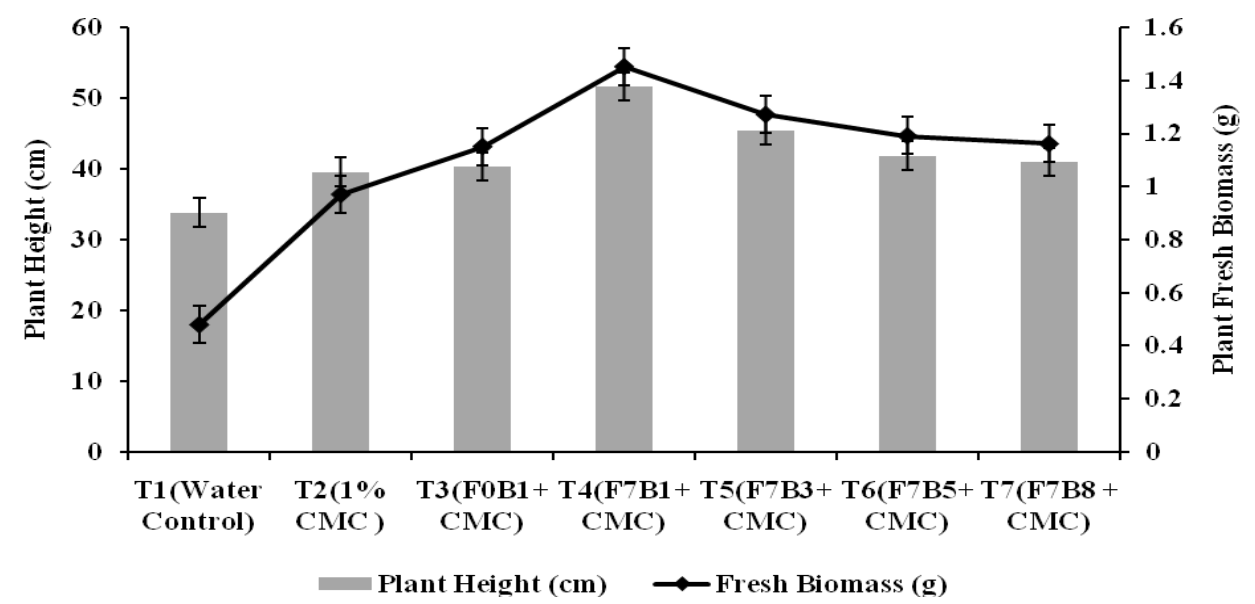


Table.5 Daily germination count of the Zea mays L. seeds and calculation of germination parameters (T1: Water control; T2: 1\% CMC; T3: F0B1; T4: F7B1; T5:F7B3; T6:F7B5; T7: F7B8), CG\% (Cumulative germination percentage).

\begin{tabular}{|c|c|c|c|c|c|c|c|c|c|c|c|c|c|c|c|c|c|c|c|}
\hline \multirow[t]{3}{*}{ Day } & \multicolumn{14}{|c|}{ Treatments (T)/Replicates (R) } & \multirow{3}{*}{$\begin{array}{l}\text { Daily } \\
\text { Total } \\
\text { (DT) }\end{array}$} & \multirow{3}{*}{$\begin{array}{l}\text { Cumulat } \\
\text { ive Total } \\
\text { (CT) }\end{array}$} & \multirow[t]{3}{*}{$\mathrm{CG}(\%)$} & \multirow{3}{*}{$\begin{array}{c}\text { Peak } \\
\text { Value }\end{array}$} & \multirow{3}{*}{$\begin{array}{l}\text { Germin } \\
\text { ation } \\
\text { Speed }\end{array}$} \\
\hline & \multicolumn{2}{|c|}{$\mathrm{T} 1$} & \multicolumn{2}{|c|}{$\mathrm{T} 2$} & \multicolumn{2}{|c|}{ T3 } & \multicolumn{2}{|c|}{ T4 } & \multicolumn{2}{|c|}{ T5 } & \multicolumn{2}{|c|}{ T6 } & \multicolumn{2}{|c|}{$\mathrm{T} 7$} & & & & & \\
\hline & R1 & R2 & R1 & R2 & R1 & R2 & R1 & R2 & R1 & R2 & R1 & R2 & R1 & R2 & & & & & \\
\hline $1^{\mathrm{st}}$ & 0 & 0 & 0 & 0 & 0 & 0 & 0 & 0 & 0 & 0 & 0 & 0 & 0 & 0 & 0 & 0 & 0 & 0 & 0 \\
\hline $2^{\text {nd }}$ & 1 & 0 & 1 & 2 & 1 & 0 & 3 & 3 & 1 & 2 & 1 & 2 & 1 & 2 & 20 & 20 & 14.29 & 7.15 & 10 \\
\hline $3^{\text {rd }}$ & 0 & 0 & 0 & 0 & 0 & 1 & 1 & 1 & 3 & 1 & 2 & 0 & 2 & 0 & 9 & 29 & 20.71 & 6.90 & 3 \\
\hline $4^{\text {th }}$ & 1 & 0 & 1 & 0 & 1 & 0 & 0 & 1 & 0 & 0 & 0 & 2 & 0 & 2 & 8 & 37 & 26.43 & 6.61 & 2 \\
\hline $5^{\text {th }}$ & 0 & 1 & 0 & 1 & 0 & 2 & 0 & 0 & 0 & 1 & 0 & 0 & 0 & 0 & 5 & 42 & 30 & 6 & 1 \\
\hline $6^{\text {th }}$ & 0 & 0 & 0 & 0 & 0 & 1 & 0 & 0 & 0 & 0 & 0 & 0 & 0 & 0 & 1 & 43 & 30.71 & 5.12 & 0.17 \\
\hline $7^{\text {th }}$ & 0 & 0 & 0 & 0 & 0 & 0 & 0 & 0 & 0 & 0 & 0 & 0 & 0 & 0 & - & - & - & - & - \\
\hline Total & 2 & 1 & 2 & 3 & 2 & 4 & 4 & 5 & 4 & 4 & 3 & 4 & 3 & 4 & 43 & - & - & - & - \\
\hline $\begin{array}{c}\text { Germinati } \\
\text { on }(\%) \\
\text { Germinati }\end{array}$ & & 0 & & & & 0 & & & & & & & & & - & - & - & - & - \\
\hline $\begin{array}{c}\text { on } \\
\text { capacity } \\
(\%)\end{array}$ & & 0 & & & & 0 & & & & & & & & & - & - & - & - & - \\
\hline
\end{tabular}


Viruel et al., (2014) have reported that Pseudomonas tolaasii EXb strain stimulated seedling emergence (8\%), shoot length (19\%), grain yield (44\%), 1000-grain weight (18\%), total dry biomass $(32 \%)$ and $\mathrm{P}$ content $(56 \%)$ of maize plants. Hameeda et al., (2008) observed that increase in maize plant biomass (dry weight) was 99\% with EB 67 (Serratia marcescens) and 94\% with CDB 35 (Pseudomonas sp.) under glasshouse conditions.

In conclusion this study highlighted the cultivable natural microbial population from Ficus tree soil as per the method of grassroots practiced by Devshankar bhai Purnashankar bhai Pandya. The results of this study showed the natural enrichment of microbe from Ficus tree soil which was having phosphate solubilization activity. Out of five phosphate solubilization positive isolates, isolate F7B1 and F7B3 showed maximum growth enhancement of Zea mays L. after $15^{\text {th }}$ DAS of treatment in pot experiment.

\section{Acknowledgement}

We are thankful to Prof. Anil K. Gupta from Indian Institute of Management, Ahmedabad for honorary supervision and support to carry out this research. Authors are also thankful to Devshankar bhai Purnashankar bhai Pandya for his practice and our scout named as $\mathrm{Mr}$. Bhatt Mahipal Mavjibhai. We are deeply indebted for the help of Mr. Ramesh Patel, Secretary of SRISTI and Alka Raval for scouting and documentation of this practice.

\section{References}

Abdul-Baki, A. and Anderson, J.D. 1973. Vigor determination in Soybean seed by multiple criteria. Crop Sci., 13: 630633.

Abiala, M.A., Odebode, A.C., Hsu, S.F. and Blackwood, C.B. 2015. Phytobeneficial properties of bacteria isolated from the rhizosphere of Maize in Southwestern Nigerian Soils. Appl. Env. Microbiol., 81(14): 4736-4743.

Bakonyi, N., Bott, S., Gajdos, E., Jakab, A., Toth, B., Makleit, P. and Veres, S. 2013. Using biofertilizer to improve seed germination and early development of Maize. Polish J. Env. Stud., 22(6): 1595-1599.

Gholami, A., Shahsavani, S. and Nezarat, S. 2009. The effect of plant growth promoting rhizobacteria (PGPR) on germination, seedling growth and yield of maize. World Acad. Sci. Eng. Technol., 49: 19-24.

Hameeda, B., Harini, G., Rupela, O.P., Wani, S.P. and Reddy, G. 2008. Growth promotion of maize by phosphatesolubilizing bacteria isolated from composts and macrofauna. Microbiol. Res., 163: 234-242.

Hussain, M.I., Asghar, H.N., Akhtar, M.J., Arshad, M. 2013. Impact of phosphate solubilizing bacteria on growth and yield of maize. Soil Env., 32(1): 71-78.

Jha, C.K., and Saraf, M. 2011. Effect of plant growth promoting rhizobacteria on seed germination behaviour and seedling vigor of Jatropha curcas plant. Int. J. Biotechnol. Biosci., 1(1):101-113.

Naik, N., and Sreenivasa, M.N. 2009. Influence of bacteria isolated from panchagavya on seed germination and seed vigour in wheat. Karnataka $J$. Agri. Sci., 22(1): 231-232.

Pandya, U., Maheshwari, D.K. and Saraf, M. 2014. Assessment of ecological diversity of rhizobacterial communities in vermicompost and analysis of their potential to improve plant growth. Biologia., 69: 968-976.

Pikovskaya, R.I. 1948. Mobilization of phosphorus in soil connection with the vital activity of some microbial species. Microbiol., 17: 362-370. 
Swaminathan, C., Swaminathan, V. and Vijayalakshmi, K. 2007. Panchagavya Boon to organic Farming, International Book Distributing Co., Lucknow.

Suslow, T.V., Schroth, M.N. and Isaka, M. 1982. Application of a rapid method for gram differentiation of plant pathogenic and saprophytic bacteria without staining. Phytopathol., 72: 917-918.

Tank, N., and Saraf, M. 2008. Enhancement o $\mathrm{f}$ plant growth and decontamination of nickel spiked soil using PGPR. J. Basic Microbiol., 49(2): 195-204.

Ustyuzhantseva, 2015. Institutionalization of grassroots innovation in India. Curr. Sci., 108(8): 1476-1482.

Viruel, E., Erazzu, L.E., Calsina, L.M.,
Ferrero, M.A., Lucca, M.E. and Sineriz, M.E. 2014. Inoculation of maize with phosphate solubilizing bacteria: effect on plant growth and yield. J. Soil Sci. Plant Nut., 14(4): 819-831.

$\mathrm{Xu}$, H.L. 2001. Effects of a microbial inoculant and organic fertilizers on the growth, photosynthesis and yield of sweet corn. J. Crop Prod., 3: 183-214.

Zinniel, D.K., Lambrecht, P., Harris, N.B., Feng, Z., Kuczmarski, D., Higley, P., Ishimaru, C.A., Arunakumari, A., Barletta, R.G. and Vidaver, A.K. 2002. Isolation and characterization of endophytic colonizing bacteria from agronomic crops and prairie plants. Appl. Env. Microbiol., 68: 2198- 2208.

\section{How to cite this article:}

Urja Pandya, Mukesh Prajapati and Nirmal S. Sahay. 2017. Cultivable Microbial Diversity Study from Traditional Formulation and Characterization of Phosphate Solubilizers through Their Effect on Vegetative Growth Parameters of Zea mays L.. Int.J.Curr.Microbiol.App.Sci. 6(4): 501-510. doi: https://doi.org/10.20546/ijcmas.2017.604.060 